\title{
VALUE INCREASING ELECTRONIC COMMERCE SOLUTIONS IN THE APPAREL INDSUTRY
}

\author{
Kathleen M. DiIorio, University of West Florida, kmd24@students.uwf.edu \\ June Wei, University of West Florida, jwei@uwf.edu
}

\begin{abstract}
Electronic commerce is critical for success in apparel industry business in the current environment. However, the adoption of electronic commerce in the electronic apparel is still behind some other industries. This study examines the major factors that can accelerate the adoption of electronic commerce in the apparel industry aiming at increasing business value. First, a strategic value chain model was examined to investigate basic apparel business activities. Second, to further develop a comprehensive view of electronic commerce solutions, electronic business segments, including business-to-business, business-to-consumer, business-to-government, and business-to-internal were investigated. Third, the value increasing attributes of these developed electronic business solutions were examined in terms of cost, quality, time, and flexibility. The findings of this paper are useful in approaching electronic business solutions and chain management in the apparel industry. The results of this study indicate that positive and negative aspects of IT adoptions exist in the apparel industry and provide useful information to industry managers and decision makers about the acceleration of electronic commerce business solutions implementation along the electronic value chain.
\end{abstract}

Keywords: Apparel Industry, Electronic Commerce, Strategic Electronic Value Chain, e-Business Solutions

\section{INTRODUCTION}

Technology has played a central role in shaping how business is conducted on many fronts in most industries. Accordingly, technology has had numerous major impacts on the apparel industry. Currently, there are several trends taking place in the industry that involve information technology and/or technological developments and advancements.

Many important developments that improve raw materials production, manufacturing processes, and construction techniques have taken place and are continuously evolving. The first of such trends is technology's continued influence on fashion and fabric, especially in terms of seasonless design and options that better meet consumer preferences and purchasing patterns (Driscoll, 2011, p. 5). Computer technology has improved design capabilities and reduced the duration of the new product development phase (Driscoll, 2011, p. 29).

Related to the trends discussed above is the vast array of improvements in apparel production facilitated by technology. First, technological innovations have fostered closer relationships with parties involved in the apparel industry supply chain, which has resulted in effective cost cutting as well as manufacturing efficiencies. Driscoll, who calls the role of technology in the apparel industry "vital," also recently reported that it is "playing a crucial role in apparel procurement (or reverse auctions) through the rising popularity of business-to-business (B2B) exchangesonline marketplaces that allow trading partners to conduct real-time business communications with each other" (Driscoll, 2011, p. 29). Additionally, quick response programs and other technologies including electronic data interchange (EDI) have made possible extremely effective inventory management, enabling manufacturers to tailor production to demand, often by instituting IT-enabled just-in-time inventory systems (Driscoll, 2011, p. 29).

Another significant technological trend in the apparel industry is the continued growth of the Internet. Standard \& Poor's predicts aggregate online retail growth of $10 \%$ in 2011 to meet the increasingly larger consumer demand for value and convenience (Driscoll, 2011, p. 3). Tied to the heavy reliance on the Internet in the apparel industry, is the emergence and growing significance of social media. Different forms of social media will likely be used for marketing purposes including the "unveiling of promotions" and publicizing of sales and events (Driscoll, 2011, p. 4). 
Mobile commerce or m-commerce facilitates commerce transactions via a mobile device such as a smartphone and other emerging mobile equipment. This form of commerce is a major technological development for the apparel industry. Mobile shopping in the U.S. grew to $\$ 3.4$ billion in 2010, more than doubling the volume in 2009 (Driscoll, 2011, p. 10). M-commerce will continue to grow and influence the apparel industry as the apparel consumer increasingly seeks information for evaluating choices, value, and convenience, all of which M-commerce supports. Additionally, Driscoll explains that, "the impetus for retailers to offer m-commerce comes from the desire to improve customer service and enhance loyalty, provide an integrated customer experience, and take advantage of new advertising opportunities” (Driscoll, 2011, p. 10). However, IT and technology adoptions in the apparel industry have not been without some challenges. Perhaps the most significant challenge in implementing e-business solutions and IT adoptions is in ensuring and maintaining security. Because of the increased number of web-based transactions, the privacy and safety of personal information has been in an issue. This problem can hopefully be aided as secure sites are increasingly used for the "checkout" process and security settings and functions are improved. Additionally, a possible hindrance with social media applications in apparel firms, as discussed above, is potential overexposure and the communication of a sale soon after a pre-markdown purchase (Driscoll, 2011, p. 10). Marketing analysts warn retailers not to expect "an immediate return on investment or increase in sales" from implementing social media applications (Driscoll, 2011, p. 10).

\section{METHODOLOGY}

In understanding value chain concepts such that they can be applied to a specific industry, such as the apparel industry, conducting research about existing industry value chain designs and infrastructures is important. There are several varying interpretations of what constitutes the value chain within the apparel industry. Many such variations are a result of differing definitions of the industry and/or represent a specific segment of the industry. Regardless of differing industry descriptions and/or segments, there are many categories and subcategories of apparel industry value chain components. Some industry analysts divide such components of the apparel industry value chain into basic essential functions, while others include several detailed facets of the process. As such, developing an original and unique idea about what an industry value chain looks like and how it is defined through examination and analysis of activities that take place during the value chain process is quite beneficial. Through such investigations, value chain activity relationships and links can be examined in terms of e-business in the apparel industry. Based on Michael Porter's strategic value chain model (Porter, 1985; Dess, Lumpkin, \& Eisner, 2010), Table 1 below illustrates the functions of each value chain activity as it has been adopted for the apparel industry value chain. All nine value chain activities are described in terms of their function within the context of the apparel industry.

Table 1: Value Chain Activity Functions and Their Relations to the Electronic Commerce Business Items in the Apparel Industry

\begin{tabular}{|c|c|c|}
\hline & Value Chain Activity & Apparel Industry Value Chain Function \\
\hline \multirow{5}{*}{ 罗 } & $\begin{array}{l}\text { Inbound Logistics } \\
\text { (B2B, B2G) }\end{array}$ & $\begin{array}{l}\text { Raw material acquisition (fibers, fabric, etc. are transported to } \\
\text { apparel factories) }\end{array}$ \\
\hline & $\begin{array}{l}\text { Operations } \\
\text { (B2B, B2G,and B2I) }\end{array}$ & Transformation of materials into apparel products \\
\hline & $\begin{array}{l}\text { Outbound Logistics } \\
\text { (B2B, B2G) }\end{array}$ & $\begin{array}{l}\text { Transfer of finished apparel goods to strategic distribution } \\
\text { channels }\end{array}$ \\
\hline & $\begin{array}{l}\text { Marketing \& Sales } \\
\text { (B2B, B2G,B2C) }\end{array}$ & $\begin{array}{l}\text { Demand analysis for strategic allocations and assortments; } \\
\text { merchandising, promotion, advertising }\end{array}$ \\
\hline & $\begin{array}{l}\text { Service } \\
\text { (B2B, B2G, B2C) }\end{array}$ & After sale servicing, return processing, inquiry response \\
\hline
\end{tabular}

Table 1 illustrates the adaptations necessary in developing an e-value chain specific to the apparel industry. Each function acts to support e-value chain processes and functionality through effective use of information technology and systems. These functions ultimately contribute to the advancement of apparel firms, enhancing overall apparel industry offerings and consumer satisfaction. e-Chain implementation can be evaluated in the context of both business segment applications and individual firm practices. Developing IT-adopted e-business solutions to be examined in terms of value added to the chain model in a particular industry is a key element in analyzing e-chain 
implementation within an industry. e-Business solutions can also be more fully understood when explored in terms of implementation within the e-value chain and within individual firms. Business segments can be categorized as business-to-business (B2B), business-to-consumer (B2C), business-to-government (B2G), and business-to-internal (B2I). These segments indicate the set of activities that take place between a firm and its vested parties, often including a variety of stakeholders. Based on discussion of IT adoptions and e-chain development, e-business solutions can be applied in each of these segments. Table 2 below outlines such activities for each business segment.

Table 2: E-Business Solutions in the Apparel Industry

\begin{tabular}{|c|c|c|}
\hline & $\begin{array}{c}\text { Item } \\
\text { Number }\end{array}$ & E-Business Solution \\
\hline & B2B-1 & Email Communication \\
\hline & B2B-2 & $\begin{array}{l}\text { Electronic Data } \\
\text { Interchange }\end{array}$ \\
\hline & B2B-3 & $\begin{array}{l}\text { Extranet Technologies } \\
\text { \& Communication }\end{array}$ \\
\hline & B2B-4 & $\begin{array}{l}\text { eCommerce for } \\
\text { Wholesale Sales }\end{array}$ \\
\hline & B2B-5 & $\begin{array}{l}\text { Electronic Order } \\
\text { Tracking }\end{array}$ \\
\hline & B2B-6 & RFID Technology \\
\hline 负 & B2B-7 & $\begin{array}{l}\text { Business Unit } \\
\text { Inventory Transparency }\end{array}$ \\
\hline & B2B-8 & $\begin{array}{l}\text { Web-Based Inventory } \\
\text { Management Systems }\end{array}$ \\
\hline & B2B-9 & $\begin{array}{l}\text { Web-Based } \\
\text { Procurement }\end{array}$ \\
\hline & B2B-10 & $\begin{array}{l}\text { Web-Based Logistics } \\
\text { Solutions }\end{array}$ \\
\hline & B2B-11 & $\begin{array}{l}\text { Web-Based Supply } \\
\text { Chain Solutions }\end{array}$ \\
\hline & B2B-12 & $\begin{array}{l}\text { Electronic Funds } \\
\text { Transfer }\end{array}$ \\
\hline & B2B-13 & $\begin{array}{l}\text { Electronic Demand } \\
\text { Forecasting }\end{array}$ \\
\hline
\end{tabular}


Volume XII, No. 1, pp. 134-140, 2011

\begin{tabular}{|c|c|c|}
\hline & B2C-1 & Email Communication \\
\hline & B2C-2 & $\begin{array}{l}\text { Electronic Information } \\
\text { Hub }\end{array}$ \\
\hline & B2C-3 & $\begin{array}{l}\text { Electronic Commerce } \\
\text { (e-commerce) }\end{array}$ \\
\hline & B2C-4 & $\begin{array}{l}\text { Customized Online } \\
\text { Customer Accounts }\end{array}$ \\
\hline & B2C-5 & $\begin{array}{l}\text { Location Search } \\
\text { Function }\end{array}$ \\
\hline & B2C-6 & Search Capability \\
\hline & B2C-7 & Customer Feedback \\
\hline$\tilde{0}_{0}^{0}$ & B2C-8 & $\begin{array}{l}\text { Electronic Shopping } \\
\text { Cart }\end{array}$ \\
\hline 尝 & B2C-9 & $\begin{array}{l}\text { Electronic Payment } \\
\text { Systems }\end{array}$ \\
\hline & B2C-10 & $\begin{array}{l}\text { Electronic } \\
\text { Order Management }\end{array}$ \\
\hline & B2C-11 & $\begin{array}{l}\text { Online Customer } \\
\text { Service }\end{array}$ \\
\hline & B2C-12 & $\begin{array}{l}\text { Electronic Gift } \\
\text { Cards }\end{array}$ \\
\hline & B2C-13 & $\begin{array}{l}\text { News Portal/Event } \\
\text { Notification }\end{array}$ \\
\hline & B2C-14 & $\begin{array}{l}\text { Credit Availability and } \\
\text { Terms }\end{array}$ \\
\hline & B2C-15 & $\begin{array}{l}\text { Human Resource } \\
\text { Functions }\end{array}$ \\
\hline
\end{tabular}




\section{Issues in Information Systems}

Volume XII, No. 1, pp. 134-140, 2011

\begin{tabular}{|c|c|c|}
\hline \multirow{5}{*}{ 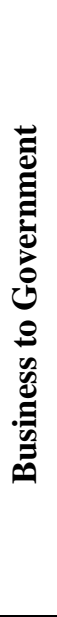 } & B2G-1 & Email Communication \\
\hline & B2G-2 & $\begin{array}{l}\text { SEC Filing \& Online } \\
\text { Information }\end{array}$ \\
\hline & B2G-3 & $\begin{array}{l}\text { IRS Tax } \\
\text { e-Filing \& Information }\end{array}$ \\
\hline & B2G-4 & $\begin{array}{l}\text { Import/Export e- } \\
\text { Records and Online } \\
\text { Information }\end{array}$ \\
\hline & B2G-5 & $\begin{array}{l}\text { Online Government } \\
\text { Contracts and } \\
\text { e-bidding }\end{array}$ \\
\hline \multirow{4}{*}{ 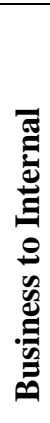 } & B2I-1 & Email Communication \\
\hline & B2I-2 & $\begin{array}{l}\text { Intranet Technologies } \\
\text { \& Communication }\end{array}$ \\
\hline & B2I-3 & $\begin{array}{l}\text { Video-conferencing \& } \\
\text { Web-casting }\end{array}$ \\
\hline & B21-4 & Internal News Portal \\
\hline
\end{tabular}

As noted above, there are thirteen IT-adopted business applications in the business-to-business segment, fifteen in the business-to-consumer segment, five in the business-to-government segment, and four in the business-to-internal segment. As the table illustrates, the fewer traditional business exchange transactions that take place within a segment, the fewer the applicable e-business solutions. Hence, there are several IT-adopted business solutions in the business-to-business segment, more in the business-to-consumer segment, and considerably fewer in the businessto-government and business-to-internal segment.

\section{FINDINGS}

Contribution to competitive priorities is another basis for measuring value added by e-business solution applications. Competitive priorities, or customer demands, can be defined as, "the critical dimensions that a process or supply chain must possess to satisfy its internal or external customers, both now and in the future” (Krajewski, Ritzman, \& Malhotra, 2010, p. 13). The e-business solutions developed in Table 2 are evaluated in the table below (Table 3) in terms of four critical customer demands: quality, cost, time, and flexibility. 


\section{Volume XII, No. 1, pp. 134-140, 2011}

Table 3: e-Business Solution Contribution to Competitive Priorities/Customer Demands

\begin{tabular}{|c|c|c|c|c|c|c|}
\hline & Quality & Cost & Time & Flexibility & Total & $\%$ \\
\hline B2B-1 & 1 & 1 & 1 & 1 & 4 & 100.0 \\
\hline B2B-2 & 1 & 1 & 1 & 1 & 4 & 100.0 \\
\hline B2B-3 & & 1 & 1 & 1 & 3 & 75.0 \\
\hline B2B-4 & & 1 & 1 & 1 & 3 & 75.0 \\
\hline B2B-5 & & & 1 & 1 & 2 & 50.0 \\
\hline B2B-6 & 1 & 1 & 1 & 1 & 4 & 100.0 \\
\hline B2B-7 & 1 & 1 & 1 & 1 & 4 & 100.0 \\
\hline B2B-8 & 1 & 1 & 1 & 1 & 4 & 100.0 \\
\hline B2B-9 & 1 & 1 & 1 & 1 & 4 & 100.0 \\
\hline B2B-10 & 1 & 1 & 1 & 1 & 4 & 100.0 \\
\hline B2B-11 & 1 & 1 & 1 & 1 & 4 & 100.0 \\
\hline B2B-12 & 1 & 1 & 1 & 1 & 4 & 100.0 \\
\hline B2B-13 & 1 & 1 & 1 & 1 & 4 & 100.0 \\
\hline Subtotal & 10 & 12 & 13 & 13 & 48 & \\
\hline$\%$ & 76.9 & 92.3 & 100.0 & 100.0 & & \\
\hline B2C-1 & 1 & 1 & 1 & 1 & 4 & 100.0 \\
\hline B2C-2 & 1 & & 1 & 1 & 3 & 75.0 \\
\hline B2C-3 & 1 & 1 & 1 & 1 & 4 & 100.0 \\
\hline B2C-4 & 1 & & 1 & 1 & 3 & 75.0 \\
\hline B2C-5 & 1 & & 1 & 1 & 3 & 75.0 \\
\hline B2C-6 & 1 & & 1 & 1 & 3 & 75.0 \\
\hline B2C-7 & 1 & & & & 1 & 25.0 \\
\hline B2C-8 & 1 & & 1 & 1 & 3 & 75.0 \\
\hline B2C-9 & 1 & 1 & 1 & 1 & 4 & 100.0 \\
\hline B2C-10 & 1 & & 1 & 1 & 3 & 75.0 \\
\hline B2C-11 & 1 & & 1 & 1 & 3 & 75.0 \\
\hline B2C-12 & 1 & & & 1 & 2 & 50.0 \\
\hline B2C-13 & 1 & & & & 1 & 25.0 \\
\hline B2C-14 & 1 & & & 1 & 2 & 50.0 \\
\hline B2C-15 & 1 & & & 1 & 2 & 50.0 \\
\hline Subtotal & 15 & 3 & 10 & 13 & 41 & \\
\hline$\%$ & 100.0 & 20.0 & 66.7 & 86.7 & & \\
\hline B2G-1 & 1 & 1 & 1 & 1 & 4 & 100.0 \\
\hline B2G-2 & 1 & & 1 & 1 & 3 & 75.0 \\
\hline B2G-3 & 1 & 1 & 1 & 1 & 4 & 100.0 \\
\hline B2G-4 & 1 & & 1 & 1 & 3 & 75.0 \\
\hline B2G-5 & 1 & 1 & 1 & 1 & 4 & 100.0 \\
\hline Subtotal & 5 & 3 & 5 & 5 & 18 & \\
\hline$\%$ & 100.0 & 60.0 & 100.0 & 100.0 & & \\
\hline B2I-1 & 1 & 1 & 1 & 1 & 4 & 100.0 \\
\hline B2I-2 & 1 & 1 & 1 & 1 & 4 & 100.0 \\
\hline B2I-3 & 1 & 1 & 1 & 1 & 4 & 100.0 \\
\hline B2I-4 & 1 & & 1 & 1 & 3 & 75.0 \\
\hline Subtotal & 4 & 3 & 4 & 4 & 15 & \\
\hline$\%$ & 100.0 & 75.0 & 100.0 & 100.0 & & \\
\hline
\end{tabular}

As is depicted above, e-business solutions help to enhance the four most critical competitive priorities. Quality and Flexibility enjoy the most value added by IT adoptions in each of the business segments. This trend occurs largely 
because many of the e-business solutions developed in Table 3 add an element of convenience to transactions, contributing to the overall quality of the end product either directly or indirectly. Flexibility is particularly enhanced because the availability and accessibility of electronically enabled exchanges and activities provides an additional channel option to traditional approaches. Some primary findings are:

(1) Out of a total of 37 e-business items, there are 19 items that can provide a $100 \%$ value increase in all four areas (quality, time, cost, and flexibility); 12 items achieve a $75 \%$ value increase in three areas; 4 items achieve a $50 \%$ value increase in two areas; and 2 items achieve a $25 \%$ value increase in one area.

(2) In the B2B category, all items can achieve a value increase in time and flexibility, $92.3 \%$ of items achieve value increase in reducing cost, and $76.9 \%$ in improving quality.

(3) In the B2C category, all items can achieve a value increase in quality and $86.7 \%$ of items achieve a value increase in flexibility; while $66.7 \%$ of items in time and $20.0 \%$ of items in cost.

(4) In the B2G and B2I categories, all items can achieve a value increase in quality, time and flexibility. With regard to cost, $60.0 \%$ of items in the B2G category and $75.0 \%$ of items in the B2I category achieve a value increase in cost.

\section{CONCLUSIONS, IMPLICATIONS, AND LIMITATIONS}

The apparel industry is a dynamic and ever-evolving and changing business environment. As discussed, exploring the many facets of e-business in the apparel industry, including those facilitated by information technology and technological advancements provides substantial insight on apparel industry operations and chain management. This study indicates that the nature of the industry calls for the thorough integration of e-business into operations as well as the incorporation of technology development. Also concluded is that it is highly important to understand previously developed value chain industry infrastructures, in this particular case, how the apparel industry value chain is constructed. Additionally, there are several benefits to a well-developed and continuously growing knowledge of value chain issues and the vast array of associated concepts and ideas. The variability of industry scenarios that require differing value chain capabilities and dynamics is a prime benefit of being able to create and understand an original value chain design. Understanding how IT adoptions can transform apparel business chains is also extremely important for the effective implementation of e-business applications. As was also discussed, it can be concluded that although the short term may be challenging, in the long term, buying and selling in the apparel industry will remain an important contribution to global economic activity and an interesting study in effective chain management and the propagation of e-business.

It should be noted that all of the 37 e-business items outlined in Table 2 and discussed above are focusing on increasing value in terms of quality, time, cost reduction, and flexibility. The items that can increase value in all four areas (that is, $100 \%$ value increase with respect to quality, time, cost, and flexibility) must be implemented first, when managers and decision makers are considering using e-business solutions to increase value. When considering other items $(<100 \%$ in all four areas), managers and decision makers must consider the trade-offs, including that quality improvements often lead to cost increases, for example. One limitation of this study is that there was no real data from companies to illustrate the e-business implementation. Future research will be conducted to collect data on top twenty companies in the apparel industry, including the use of benchmarks to analyze the implementation patterns of the discussed e-business solutions.

\section{REFERENCES}

1. Driscoll, M. (2011, March 10). Apparel \& footwear: retailers \& brands. Standard and Poor's Industry Surveys. Retrieved April 1, 2011 from Standard and Poor's NetAdvantage.

2. Porter, M. (1985). Competitive advantage: creating and sustaining superior performance. New York, NY: The Free Press.

3. Krajewski, L., Ritzman, L., \& Malhotra, M. (2010). Operations management: processes and supply chains. Upper Saddle River, NJ: Pearson Prentice Hall.

4. Dess, G. G., Lumpkin, G. T., \& Eisner, A. B. (2010). Strategic management: text and cases. New York, NY: McGraw-Hill Irwin Companies, Incorporated. 